\title{
A Study on a Short-Term English Immersion Program
}

\author{
JeongYou-Jin ${ }^{1}$ and Kang Mun-Koo ${ }^{2 *}$ \\ Department of English Education, Kongju National University, 56 Gongjudaehak- \\ Ro, Gongju-Si, Chungcheongnam-Do, 314-701, South Korea \\ ${ }^{1}$ jeongyujin9844@hanmail.net, ${ }^{2 *}$ kangmunkoo@hanmail.net
}

\begin{abstract}
This study reflects the best approach to a short-term English Immersion Program. In order to overcome the restrictions that the Korean English education system has, English camps for students have been proposed by the Korean Education system as a solution for improving Korean students' English ability. The purpose of this research is to analyze the characteristics of a short-term English Immersion program during a middle school English camp. This study was conducted at an Institute in C province, during a short-term English camp for middle school students, including dormitory residency. This research focused on three different sections: Firstly, the TBL classes that are taught by a native English-speaking teacher. Secondly, the research also looked at EEC activities, which are co-teaching classes that are taught by a Korean teacher and a native Englishspeaking teacher. Thirdly, the research focus covered communicative activities that are carried out by all students and every teacher during each and every camp. Communicative activities include icebreakers, performances, sporting events, fun farewell and journal writing. However, there were some questions raised regarding this. The specific research questions for this study are as follows: First of all, what do students feel most comfortable with among the three different situations? Secondly, do they experience some changes within themselves? With these questions in mind, this study will progress so as to analyze this program. Over a period of four days, students encounter three different kinds of learning situations as we've mentioned. Students who take part in this Immersion program are from different kinds of schools. At first, they feel nervous and embarrassed with many native English-speaking teachers and their challenge of having to speak English. However, at the end of the camp, students are all satisfied with this program. Their anxieties are decreased and their motivation to study English is increased. Contrary to our expectations, when students encounter native English-speaking teachers without a Korean teacher, students feel confident as well. The following are suggestions based on these research findings. This study was conducted on students who are chosen to study English outside their normal school environment. Korean students have little trust in their conventional public school teaching and learning environment and seek alternative methods of learning English. The Korean government should encourage and grow public Institutes and plan more immersion programs in order to save parents money that is currently being spent on private academies. Furthermore, this immersion camp should be strongly recommended as an alternative to EFL English education. This paper would also recommend the introduction of a new curriculum that could be applied to Korean students as well as adult learners.
\end{abstract}

Keywords: TBL (Task-Based Learning), EEC (English-Experience Center Activities)

\section{Introduction}

Even though people know the importance of communicative competence, Korean

* Corresponding Author 
education focuses on how many answers students get right from school exams or the Korean SAT. In the Korean curriculum, students start learning English from third grade in Elementary school. However, many students still have a problem speaking English with native English speakers.

Recently, the education office has taken steps to reduce the number of native Englishspeaking teachers who are working in public and private schools by cutting the budget. We need an alternative to these changes as English is an important language all over the world. Graddol (2006) emphasizes that the relationship between English and globalization could not be separated as economic globalization encourages the spread of English and the spread of English also encourages globalization. In a globalized world, English becomes a universal language in communicating with people around the world using a common language. Students' English proficiency will affect their future, career, and education. According to Graddol (2006), as of the year 2000 there were 750 million English as Foreign Language speakers and 375 million English as Second Language speakers. A huge number of people are currently learning English worldwide. In terms of globalization, Graddol points out that many governments around the world encourage their country to be bilingual. In addition, many governments enforce English immersion education in schools. In South Korea, there is no doubt that a high number of people emphasize the importance of English competence now that we live in a globalized world.

This Institute located in $\mathrm{C}$ province has an English immersion program for middle school students, including dorm residency. This program can be categorized into three sections: English Experience Center Activity, Task Based Learning, and Whole Learning. This paper will be studying the sections that students feel comfortable with. We strongly believe that the purpose of this immersion program is to relieve students' debilitative anxiety, to give them chances to meet native English-speaking teachers face to face and also to create an English learning environment in which a variety of teaching methods can be used. Some people are skeptical of Korean public schools that have hired a native English-speaking teacher. This is because the budget consumed has been vast and yet the improvement seen in the students' English ability has been minimal.

Another critical issue of this short-term English immersion program is the question of how a student's English ability can be improved in a short period of time. To explore an answer to this question, this study suggests that we need to impact positively on students motivational levels and their affective filter.

\section{Immersion Program}

Baker (2006) explains that there are generic levels of entry into Language immersion education divided according to age. First, in 'early immersion' programs, students begin to learn a second language from the age of 5 or 6 . Second, in 'middle immersion' programs, students begin to learn the second language from the age of 9 or 10 . Third, in 'late immersion' programs, students begin the second language between ages 11 and 14 . The classes are not repetitive in nature, which means that students do not learn the content in L1 and again in the L2 (Deveau \& Band, 2004). Pacific Policy Research Center (2010) explains, in programs that utilize immersion language education, students may enter and begin studies at a different age and at different levels. The research shows that early immersion in a second language is preferable to late immersion. Two main types of immersion can also be found in literature; including total immersion, and partial immersion. In total immersion, almost $100 \%$ of the school day is spent in L2, meaning that almost all subjects will be taught in the L2. Partial immersion programs vary in their L2 emphasis, spending only some of the class time in the target language.

In Korea, a short-term English camp and an immersion program for an intensive foreign language education has become one of the most popular methods for English immersion programs as well as a prosperous English Language Teaching business. Some 
studies were conducted on the effectiveness of English camp programs that were developed for university students, elementary, and secondary students. All the programs were developed by universities, and their common goal was to develop the participants' English communicative skills and confidence. Listening skills and confidence in learning English were found to be the most enhanced areas. All the participants were Korean learners of English and were taught by native English instructors.

Park (2009) points out Korean parents invest a large portion of their income into their children's education. The education includes all extracurricular lessons such as cram school, private tutoring, and English camps. There are a variety of English camp programs offered every year by private language schools and companies with or without overseas partners. It is suggested that an English immersion camp is an alternative way of improving L2 language communicate skills, as well as intercultural understanding (Park, 2006). In Korea, it can be seen as a big issue since parents pay a lot of attention to English education for their children and promote the idea of English immersion programs.

According to Vines' (1985) definition, language camp provides the opportunity for participants to engage in foreign culture-related activities that are not traditionally part of the classroom curriculum. This immersion program is to improve students' English ability and has three fields. The schedule of this program is from 9 a.m. to 9 p.m., including dorm residency.

The main program has three sections of English learning. First of all, we have TBL classes, which are Task-Based Learning classes. Native English teachers choose a subject that they like or are confident with and manage their classes in their own way. In a classroom, there is one native teacher and 13 students. Students have the opportunity to do a variety of activities covering different subjects. Secondly, we have EEC classes, which are English Experience Center activities. For these classes, one Korean teacher and one native English teacher lead the class. Our institute is equipped with eight venues that are authentic in English speaking countries. Students learn essential expressions during classes and then practice these expressions in the authentic venues. Thirdly, we have communicative activities. Sometimes 3 Korean and 3 native English teachers participate in some of the whole class teaching activities. At other times, 10 native English teachers and 7 Korean teachers join the same program with 70 or 80 students. The impact of the three different kinds of learning situations will be discussed in more detail in the research article that follows.

Table 1. Curriculum of English Camp

\begin{tabular}{|c|c|c|c|}
\hline Section & Subjects & Description & Hour \\
\hline \multirow[t]{7}{*}{ EEC Activity } & Airport & \multirow{7}{*}{$\begin{array}{l}\text { To explore and to apply } \\
\text { situational dialogues at } \\
\text { classroom and venue }\end{array}$} & 1 \\
\hline & Hotel & & 1 \\
\hline & Fast Food & & 1 \\
\hline & Clinic \& Pharmacy & & 1 \\
\hline & Street & & 1 \\
\hline & Superstore & & 1 \\
\hline & Post Office & & 1 \\
\hline \multirow[t]{3}{*}{ TBL } & $\begin{array}{l}\text { What does the fox } \\
\text { say? }\end{array}$ & $\begin{array}{l}\text { To learn about how to make an } \\
\text { onomatopoeia }\end{array}$ & 1 \\
\hline & Comic & $\begin{array}{l}\text { To learn English sounds words } \\
\text { by web comics }\end{array}$ & 1 \\
\hline & Art & $\begin{array}{l}\text { To enhance creativity by } \\
\text { enhancing famous pictures }\end{array}$ & 1 \\
\hline
\end{tabular}




\begin{tabular}{|c|c|c|c|}
\hline & Airplane Dynamics & $\begin{array}{l}\text { To find out scientific principles } \\
\text { behind an airplane }\end{array}$ & 1 \\
\hline & Astronomy & $\begin{array}{l}\text { To create a moon chart in groups } \\
\text { of four with their cookies }\end{array}$ & 1 \\
\hline & Eggs Drop & $\begin{array}{l}\text { To learn about gravity through } \\
\text { eggs drop experiment }\end{array}$ & 1 \\
\hline & Film Appreciation & $\begin{array}{l}\text { To examine and categorize } \\
\text { movies based on different genres }\end{array}$ & 1 \\
\hline & American Football & $\begin{array}{l}\text { To say the rules and play the } \\
\text { game }\end{array}$ & 1 \\
\hline & Emoticons & To design their own emoticons & 1 \\
\hline & Ooblecks & To understand states of matter & 1 \\
\hline & Home Cooking & To learn how to bake muffin & 1 \\
\hline & $\begin{array}{l}\text { Marshmallow } \\
\text { Challenge }\end{array}$ & $\begin{array}{l}\text { To use their creativity by } \\
\text { building a structure with } \\
\text { spaghetti }\end{array}$ & 1 \\
\hline \multirow[t]{7}{*}{$\begin{array}{l}\text { Communicative } \\
\text { Activity }\end{array}$} & Performance & $\begin{array}{l}\text { To prepare for "Tonight at } \\
\text { CIFLE performance" }\end{array}$ & 4 \\
\hline & Ice Breakers & $\begin{array}{l}\text { To play a language game to } \\
\text { break the ice }\end{array}$ & 1 \\
\hline & Fun Farewell & $\begin{array}{l}\text { To dismiss the Ss with camp } \\
\text { feedback }\end{array}$ & 1 \\
\hline & Mission Impossible & $\begin{array}{l}\text { To participate in team spirits } \\
\text { projects }\end{array}$ & 1 \\
\hline & Tonight at CIFLE & $\begin{array}{l}\text { To play a performance } \& \text { have a } \\
\text { BBQ party }\end{array}$ & 2 \\
\hline & CIFLE Olympics & To engage in 5 games as a team & 1 \\
\hline & Journal & To keep a journal & 3 \\
\hline \multirow[t]{2}{*}{ Other Events } & Opening/Closing & Opening and Closing ceremony & 2 \\
\hline & Program Evaluation & Survey about the camp & 1 \\
\hline
\end{tabular}

\subsection{TBL (Task-Based Learning)}

According to Krashen's Affective Filter Hypothesis (1982), low motivation, low selfesteem, and debilitating anxiety can combine to raise the affective filter and form a mental block that prevents comprehensible input from being used for acquisition. The theory says that people with a low level of anxiety are better equipped for success in second language acquisition. Before coming to work here, we thought that students feel lots of anxiety only when they are with a native English teacher. Having personally worked at this institute, what we expected before has not happened. An important aspect of teaching that we have witnessed is that the actual act of teaching has an undeniable impact on a student's level of anxiety. While observing this immersion program, we have noticed that native English teachers have tried to create an embracing atmosphere to lessen students' anxiety.

This study required an examination of classes that are done by native teachers. In this immersion program, students have six TBL classes for four days. The classes are all designed by native English teachers, where they choose the field that they are confident with. The classes vary from American Football, Forensic Science, Reading Activity, Astronomy, Economics, and Marshmallow Building to Film Appreciation. These activities are all performed by one native English teacher and 12 students. The goals of 
all activities are for students to communicate and complete the given task. Students have to participate in the activities and they cannot get a free ride.

In order to appreciate the reason why students enjoy these classes, a detailed explanation of each lesson should be included. In the American Football class, students learn about basic rules of American football, including some simple vocabularies and terms used. Students practice those terms through a simulated PowerPoint game and then play a game using paper as a football, incorporating sport rules. Students, especially boys, like to learn kinesthetic sports rules and terms. In the Forensic Science class, students learn new terms relating to each finger and get to scan their own fingerprints just like police officers do in the movies. In the Astronomy class, students learn phases of the moon and try to make various types of moons using Oreo cookies. In Marshmallow Building class, students try to build a tall structure or tower using spaghetti noodles and marshmallow.

The characteristics of TBL classes include kinesthetic activities aimed at inducing their participation. While students are trying to complete their given task, they are encouraged to speak English and are praised for their participation in the lesson. Students are absorbed in the task and do not feel any debilitative anxiety when speaking English. Without a Korean teacher, if they accomplish the given roles, the student's level of satisfaction is higher. They try to solve the problems by themselves. Some people say that the limitation of a TBL class is that they focus on the meaning, instead of the form. But I believe that this also has a positive effect on a student's affective factor. Students feel free to speak in English when they are away from grammar rules. Students need time to take a break from English grammar, so that they can enjoy English just for fun with a native English-speaking teacher. Also, some of the limitations of a TBL class are compensated for by a worksheet activity and the teacher's classroom question and answer teaching method.

Table 2. Sample Lesson Plan for TBL

\begin{tabular}{|c|l|c|}
\hline Subject & \multicolumn{1}{|c|}{ Sports English } & NT \\
\hline Objectives & $\begin{array}{l}\text { To correctly use the words 'go', 'do', and 'play' in relation to sports } \\
\text { To participate in the game of badminton }\end{array}$ & $\begin{array}{l}|c| \\
\text { Activities } \\
\text { (mins) }\end{array}$ \\
\hline Procedures & \multicolumn{1}{|c|}{} & 3 \\
\hline Presentation & $\begin{array}{l}\text { 1) Ss will identify what the sports are thru matching. } \\
\text { 2) Ss will review the verbs 'go' 'do' and 'play' and their } \\
\text { use with sports thru a PPT presentation. }\end{array}$ & 6 \\
& $\begin{array}{l}\text { 3) Ss will complete exercises based on matching the } \\
\text { sports with the correct verb. }\end{array}$ & 10 \\
Product & $\begin{array}{l}\text { 4) Ss will identify the equipment and key terms for } \\
\text { badminton. }\end{array}$ & 5 \\
& $\begin{array}{l}\text { 5) Ss will 'play' badminton outside on the grass. } \\
\text { 6) Ss will go back to class for a review session of } \\
\text { questions and key vocab. }\end{array}$ & 5 \\
\hline
\end{tabular}

\subsection{EEC (English-Experience Center Activities)}

This institute is equipped with eight venues that are authentic in English speaking countries. The venues are airport, fast food restaurant, hotel, home, tourist center, street, superstore, clinic, pharmacy and post office. Among them, students have six EEC classes for four days. Each class is 45 minutes, of which half of the lesson is conducted in the classroom and the rest are done in the EEC venue. Students have enough time to practice the new words and expressions in the classroom before they move to the English Experience Center. 
The EEC venues start with the airport class where they practice the dialogue. Students learn how to do ticketing, security check, immigration, baggage claim and customs. Students can be a ticketing agent, security officer, flight attendant or immigration officer. After that, students proceed to the fast food restaurant and learn how to order some food in English. There, students can be a clerk, waiter or waitress. Next, they are divided into two groups and some of them make a reservation at a tourist center while others practice being a hotel clerk. The students practice check in and check out dialogue. In a superstore venue, students learn the different kinds of departments and practice how to shop in English. Students can also go to the clinic and pharmacy and pretend to be a doctor, pharmacist, or patient. Students who practice being a patient go to see a doctor and consult what their symptoms are. Students who practice being a doctor prescribe medication and give it to the patient. After getting a prescription from a doctor, students move to a pharmacy and get medicine from a student who practices being a pharmacist. In the post office, students practice mailing a postcard and a package while being a postman, post woman or client. Also, students learn the usage of prepositions and direction words in order to follow the street regulations.

The distinctive feature that I want to mention is that the EEC classes are performed using a team-teaching method between a Korean teacher and a native English teacher. According to Friend and Reising (1991), there are five types of team teaching methods. These are: lead and support type, station teaching, parallel teaching, alternative teaching and collaborative teaching.

This institute has incorporated parallel teaching and collaborative teaching into the classes. The teaching method chosen varies according to the activity that is being taught. Parallel teaching involves two teachers planning a lesson together before class, but during the class, each teacher takes charge of his or her own section. In some venues such as clinic and pharmacy, fast food and restaurant, teachers choose the parallel teaching method. Students are then divided into two groups, and each teacher takes charge of half of a group and then exchanges students. Collaborative teaching takes place when two teachers have planned together and then teach for the whole time together. In the post office or the home venues, teachers choose this teaching method.

The benefit and advantage of this method is that Korean teachers have a chance to communicate with native teachers during lesson plan preparation and teaching. This helps in improving listening and speaking skills a lot. Another positive aspect is that Korean teachers can experience new teaching styles that they may not have used before. But when the question of whether students feel more comfortable with both Korean and native English teachers teaching together or with a native English teacher teaching alone arises, the answer differs according to the student's level. Students who have had less of a chance to meet a foreign teacher rely on a Korean teacher's translation and they feel more comfortable with having a Korean teacher in the classroom. But the students who are extroverted are confident with their English even though they speak only one or two words in English. 
Table 3. Sample Lesson Plan for EEC Class

\begin{tabular}{|c|c|c|}
\hline Subject & HOTEL & NT,KT \\
\hline Objectives & $\begin{array}{l}\text { To familiarize students with commonly used vocabulary when g } \\
\text { To allow students to practice dialogs in realistic situations. }\end{array}$ & ing to a hotel. \\
\hline Procedures & Activities & $\begin{array}{l}\text { Time } \\
\text { (mins) }\end{array}$ \\
\hline $\begin{array}{c}\text { Stage 1 } \\
\text { (Classroom) }\end{array}$ & $\begin{array}{l}\text { NT: Talk about why we stay in a hotel; vacation, business. } \\
\text { Other things to do in a hotel - restaurants, gym, swimming pool } \\
\text { * Vocabulary: NT does vocab, KT clicks } \\
\text { * NT and KT role play check-in } \\
\text { * Play matching vocab game on www.barryfunenglish.com } \\
\text { - KT chooses students to pick numbers, NT clicks numbers } \\
\text { * PPT and dialogs: NT first half, KT dialogs } \\
\text { * Students to practice dialogs in PPT. } \\
\text { - Spelling game on white board } \\
\text { * EEC: NT half, KT half students } \\
\text { * Students to role-pay various dialogs in EEC. Allocate roles to } \\
\text { students; front desk and guests. Hand out credit cards and } \\
\text { hotel key cards. } \\
\text { * Hand "Spot the difference" worksheets to students to keep } \\
\text { them busy after they've done the dialog. } \\
\text { If time, do quick quiz in EEC. Dismiss to new class. }\end{array}$ & $\begin{array}{c}2 \\
10\end{array}$ \\
\hline
\end{tabular}

\subsection{Communicative Activity}

This immersion program has several communicative activities, which are performed by every teacher and every student. The classes include one Icebreaker activity, four Drama Performances, one Mission Impossible, one BBQ party and one Fun Farewell.

According to Scott and Ytreberg (1990), a good language game motivates students to learn in the classroom and spurs them on to continue studying outside the classroom. It is obvious that students like to play a game, even though it is done in English. But careful planning is important to ensure an effective lesson when working with large class sizes. This immersion program provides many opportunities to play many games.

In the class of Icebreakers, students are divided into six groups made up of 7 or 8 members. One native English teacher takes charge of the whole class and leads several language games to break the ice with all group members. Three native English teachers and three Korean teachers stand beside each small group and help them understand the game rules better when students feel confused. Examples of these games include: national geography, the best game, pass the ball, picture catch or code breaker. As a small group member, students try to answer each question correctly and enjoy the games by competing against one another. Because the learning materials do not require a student's prior knowledge, they can do this activity just for fun.

The class of Mission Impossible is a kind of treasure hunt. For 30 minutes, each team reads a clue card and then goes to find the book that contains the answer. Team members should move together by holding a rope and taking on a role such as captain, moral guide, headcounter, timekeeper, question master or navigator. From this game, students develop a team spirit.

In the Drama Performance class, students can prepare a short English skit and dramatize their roles. According to their performance script, students can become a variety of animals, a king, a queen, or a movie character like the Hulk. We have many costumes that are suitable with the roles. The four classes consist of the preparation of reading warm-ups, physical warm-ups, vocal warm-ups and rehearsal. Charlyn Wessel 
(1987) said that drama is a kind of technique to produce in students the need to speak and make them involved in the learning process. During the first Drama Performance class, students feel stressed and try to take a role that has fewer lines. While they go through the steps of reading, acting, and adding emotion, students help each other to make a better drama and try to enhance their potential during the rehearsal time; they feel like becoming actors or actresses and try to make their drama more elaborate and sophisticated. On the last day of English camp, every member in this camp gets together in the auditorium. They then take turns to exhibit their group performance one by one.

During the BBQ party, native English teachers serve students their food and the students stand in line, asking them, "May I get a ?" They repeat the sentence and receive what they request. Through this activity, students feel confident with their English because they say a sentence, not pointing at the food that they want, and they get something to eat or drink. Students do not think that this environment is for learning English; they are just immersed in an English speaking situation in a very natural way.

\section{Research Methodology}

Whenever each English camp finishes, this institute conducts an online survey for the students. For this study, we designed two types of survey pre and post-study. On the first day, students get a pre-survey questionnaire of 30 questions, which requires them to assess their current ability with English language usage. Following the camp, there is a post-survey of 35 questions. These questions are phrased in Korean to enable students to gather a clear idea about their meaning. Also, these questions cover the levels of satisfaction enjoyed by each student during the camp. The post-survey also covers the three main areas of teaching and learning in each camp: TBL, EEC, and CA and asks them to review such matters as its usefulness and their understanding in learning English, as well as the level of fun enjoyed over the period of the camp. Also, some students have time to talk with Korean teachers in Korean after each class.

The researcher of this study analyzed the answers which the participants gave and the reasons from the questionnaires and students feedback were analyzed into common and identified categories that we have formulated in tables below in 3.2 with regards toe these categories.

\subsection{Participants}

The interview and survey below was given to the 70 students who participated in the English camps. All 70 students were second graders of middle school age according to this specific survey. There were 43 girls and 27 boys. Most students have studied English for at least four years. They are all from the towns located in $\mathrm{C}$ province.

\subsection{Survey Contents}

Pre-survey contents are reflected in the following table:

Table 4. Pre-Survey

\begin{tabular}{|c|l|c|}
\hline Question & \multicolumn{1}{|c|}{ Contents } & Type \\
\hline 1 & Grade & multiple \\
\hline 2 & The length of studying English & multiple \\
\hline 3 & The way of studying English & multiple \\
\hline 4 & The experience of English camp & multiple \\
\hline $5 \sim 12$ & Self-confidence & 5-step scale \\
\hline $13 \sim 17$ & Interest in English & 5-step scale \\
\hline $18 \sim 23$ & Anxiety & 5-step scale \\
\hline $24 \sim 30$ & Motivation & 5-step scale \\
\hline
\end{tabular}


Post-survey is mainly about self-satisfaction, their favorite activities and the questions covered:

Table 5. Post-Survey

\begin{tabular}{|c|l|c|}
\hline Question & \multicolumn{1}{|c|}{ Contents } & Type \\
\hline 1 & Grade & multiple \\
\hline 2 & Self-confidence & 5-step scale \\
\hline 3 & Interest in English & 5-step scale \\
\hline 4 & Interest in English after camp & 5-step scale \\
\hline $5 \sim 10$ & Do you like OOO class from TBL class? & 5-step scale \\
\hline $11 \sim 16$ & Do you like OOO class from EEC class? & 5-step scale \\
\hline $17 \sim 22$ & Do you like OOO class from communicative activity? & 5-step scale \\
\hline $23 \sim 26$ & Anxiety & 5-step scale \\
\hline $27 \sim 30$ & Motivation & 5-step scale \\
\hline $31 \sim 35$ & Self-esteem & 5-step scale \\
\hline
\end{tabular}

\subsection{Analysis of Survey}

The survey questionnaire consists of items regarding students' self-esteem, anxiety, motivation, and interest in English. I'd like to show several items among them, which are the following:

Table 6-1. Comparing Pre-Camp to Post-Camp

\begin{tabular}{|c|l|c|c|c|}
\hline Category & \multicolumn{1}{|c|}{ Contents } & N & Pre & Post \\
\hline Self-esteem & $\begin{array}{l}\text { I am good at listening /speaking. } \\
\text { I'm good at reading / writing. }\end{array}$ & 70 & 3.45 & 3.47 \\
\hline Anxiety & $\begin{array}{l}\text { I'm nervous during English class. } \\
\text { I'm afraid of talking with a native teacher. } \\
\text { I'm more comfortable when a Korean teacher translate } \\
\text { English into Korean. }\end{array}$ & 70 & 2.66 & 2.69 \\
\hline Motivation & $\begin{array}{l}\text { I have to learn English because English is an important } \\
\text { subject. } \\
\text { I try to improve my English outside an English class. }\end{array}$ & 70 & 3.97 & 3.99 \\
\hline $\begin{array}{c}\text { Interest in } \\
\text { English }\end{array}$ & $\begin{array}{l}\text { I'm interested in the English class. } \\
\text { I think that English is an important subject. } \\
\text { I like to talk to friends in English. }\end{array}$ & 70 & 3.76 & 3.83 \\
\hline
\end{tabular}

The table above shows each category that we surveyed initially during the pre-camp survey. The most distinctive feature in the survey was the criteria that covered the category of students' level of anxiety increased positively in the post-camp survey. Before meeting native English teachers, students are nervous and concerned about not understanding what native English teachers will instruct during the class. When the camp is over, students feel more familiar with native English teachers and believe that they have learned something beneficial to them.

However, the question of whether students are good at reading shows a slight decrease. 
Table 6-2. Students' Response in Post-Survey

\begin{tabular}{|c|l|c|}
\hline Category & \multicolumn{1}{|c|}{ Contents } & Result \\
\hline TBL Class & $\begin{array}{l}\text { (TBL) Do you think that Forensic Science class is } \\
\text { beneficial and interesting? }\end{array}$ & Average 4.79 \\
\hline EEC Class & $\begin{array}{l}\text { (EEC) Do you think Airport class is beneficial and } \\
\text { interesting? }\end{array}$ & Average 4.81 \\
\hline CA Class & $\begin{array}{l}\text { (CA) Do you think Mission Impossible class is } \\
\text { beneficial and interesting? }\end{array}$ & Average 4.75 \\
\hline
\end{tabular}

\section{Conclusion}

In this paper, we have analyzed the short-term immersion program and observed the students' interest and motivation in speaking English in this situation. This study focuses on these three different teaching sections: a TBL class with a native English-speaking teacher, an EEC class with a Korean teacher and a native English-speaking teacher and a communicative activity with a whole class teaching method.

In comparing all of them, the following conclusions were drawn: First, a student's debilitative anxiety does not hinder their motivation for learning English whether there is a Korean teacher or not. Rather, the important thing is what teaching technique a teacher uses and how well the teacher manages the class. The lesson plan should be studentcentered and the activities authentic and kinesthetic. Teachers have to inspire the students to participate in the class. Second, students feel more satisfaction when they can understand and finish a given task with no help from a Korean teacher. In an Englishspeaking atmosphere, students do not have as much pressure regarding grammatical rules as that imposed on by the Korean schooling system. They learn English naturally and they also learn English culture through a native English-speaking teacher. Finally, students should be provided with more opportunities to speak English and need to attend more classes like this program provides.

Some private institutes have English immersion programs during vacation periods but they are too expensive to draw a lot of people's participation. Therefore, I strongly suggest that the Korean government should encourage public institutes to plan more immersion programs in order to expose students to the target language and reduce private education expenses. Furthermore, I would also recommend the creation of an affective curriculum targeting the wider Korean populace, including teachers and adult learners.

\section{References}

[1] C. Baker, "Foundations of bilingual education and bilingualism", Clevedon; Buffalo: Multilingual Matters, (2006).

[2] H. D. Brown, "Affective variables in Second language acquisition”, Language Learning, (1973).

[3] H. D. Brown, "Principles of language learning and teaching (4th ed.)", Plain, New Work: Pearson Education, (2000).

[4] C. Wessel, Drama, Oxford; OCP, Resource Books for Teachers, (1987).

[5] D. Deveau and Y. J. Bang, "Developing an immersion program in the Korean EFL context", The Modern English Education Society, vol. 1, no. 5, (2004).

[6] M. Friend, M. Reising and L. Cook, "Co-teaching: An overview of the past, a glimpse at the present, and considerations for the future", Preventing School Failure, (1993).

[7] D. Graddol, "English next", British Council, (2006).

[8] E. J. Kim, "A Multi-Perspective Approach to Investing Perceptions of English Immersion Programs in South Korea", (2012).

[9] S. Y. Kim, "The Effects of Short-term English Camp Program on Elementary School Students' Affective Domain, (2014).

[10] S. D. Krashen, "Principles and practice in Second Language Acquisition", Oxford: Pergamon, (1982).

[11] H. M. Kwak, "The Types and Perception of the Teacher's Scaffolding in an English Immersion 
Environment: Focusing on Five-year-old Children in English Kindergarten”, (2014).

[12] Pacific Policy Research Center: Successful bilingual and immersion education models/programs. Honolulu: Kamehameha Schools, Research \& Evaluation Division, (2010).

[13] J. K. Park, "Korea-Japan English camp; a case study if English immersion program in Korea", English Language \& Literature Teaching, vol. 4, no. 12, (2006).

[14] J. K. Park, "The development of English immersion education in Korea", English Language \& Literature, vol. 22, no. 21, (2009).

[15] S. H. Park, "A study of understandings and perceptions about English immersion education in elementary schools. Foreign Languages Education, vol. 2, no. 16, (2009).

[16] W. A. Scott and L. H. Ytreberg, "Teaching English to Children", Harlow: Longman, (1990).

[17] L. Vines, "A guide to Language camp in the U.S.: 2", Language in Education: Theory and Practice, no. $53,(1985)$.

\section{Authors}

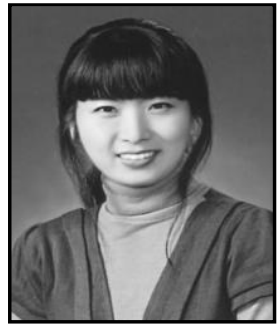

You-Jin Jeong, Secondary School Teacher. She is an English teacher in Korea. She also studies English education and English grammar in the Ph.D. course at the graduate school of Kongju National University.

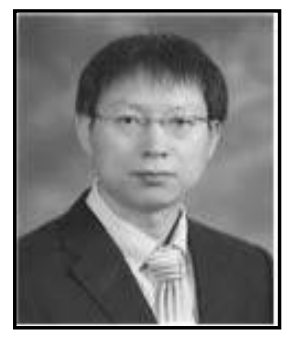

Mun-Koo Kang, (Corresponding Author), he works for Kongju National University. He has a Ph.D. in English grammar. He also serves as a committee of various academic societies in Korea. 
International Journal of $u$ - and e- Service, Science and Technology Vol.9, No. 10 (2016) 